\title{
Correction to: A super-spreader of SARS-CoV-2 in incubation period among health-care workers
}

Chaojie Wei ${ }^{1,3}$, Yufeng Yuan ${ }^{2}$ and Zhenshun Cheng ${ }^{1,3^{*}}$

\section{Correction to: Respir Res (2020) 21:327}

http://doi.org/10.1186/s12931-020-01592-w

Following publication of the original article [1], we were notified that a funding note needs to be added to the Funding section: "Ministry of Science and Technology of the People's Republic of China (Grant No. 2020YFC0845500)."

The original paper has been corrected.

\section{Author details}

1 Department of Pulmonary and Critical Care Medicine, Zhongnan Hospital of Wuhan University, No.169 Donghu Road, Wuhan 430071, China. ${ }^{2}$ Department of Hepatobiliary Surgery, Zhongnan Hospital of Wuhan University, No.169 Donghu Road, Wuhan 430071, China. ${ }^{3}$ Wuhan Research Center for Infectious Diseases and Cancer, Chinese Academy of Medical Sciences, No.169 Donghu Road, Wuhan 430071, China.

Published online: 19 January 2021

\section{Reference}

1. Wei C, Yuan Y, Cheng Z. A super-spreader of SARS-CoV-2 in incubation period among health-care workers (PHYSSURG-C): study protocol for a randomised controlled trial. Respir Res. 2020;21:327. https://doi. org/10.1186/s12931-020-01592-w.

\section{Publisher's Note}

Springer Nature remains neutral with regard to jurisdictional claims in published maps and institutional affiliations.
The original article can be found online at https://doi.org/10.1186/s1293 1-020-01592-w.

\footnotetext{
*Correspondence: zhenshun_cheng@126.com

1 Department of Pulmonary and Critical Care Medicine, Zhongnan

Hospital of Wuhan University, No.169 Donghu Road, Wuhan 430071,

China

Full list of author information is available at the end of the article
} original author(s) and the source, provide a link to the Creative Commons licence, and indicate if changes were made. The images or other third party material in this article are included in the article's Creative Commons licence, unless indicated otherwise in a credit line to the material. If material is not included in the article's Creative Commons licence and your intended use is not permitted by statutory regulation or exceeds the permitted use, you will need to obtain permission directly from the copyright holder. To view a copy of this licence, visit http://creativecommons.org/licenses/by/4.0/. The Creative Commons Public Domain Dedication waiver (http://creativeco mmons.org/publicdomain/zero/1.0/) applies to the data made available in this article, unless otherwise stated in a credit line to the data. 